\title{
相対的強度の等しい前腕と下眼の同時運動に対する呼吸循環系応答
}

\author{
加賀谷淳子* 水口由 紀** 高平稚子*** 片山幸子****
}

\section{RESPIRO-CIRCULATORY RESPONSES TO FOREARM AND \\ CALF EXERCISE PERFORMED SIMULTANEOUSLY \\ AT AN EQUAL FRACTION OF MVC}

\author{
Atsuko Kagaya, Yuki Minakuchi, Wakako Takahira \\ and SaCHIKo KataYAMA
}

\begin{abstract}
Respiro-circulatory responses to forearm and calf exercise performed simultaneously were compared with corresponding responses to forearm or calf exercise performed separately in 9 active women aged $21.1 \mathrm{yr}$ on average. Handgrip exercise and plantar flexion were carried out for $60 \mathrm{~s}$ in a supine position at a frequency of 60 times $\bullet \mathrm{min}^{-1}$ and the load was adjusted to $1 / 3$ MVC. Forearm blood flow (FBF) increased to $9.64 \pm 1.00 \mathrm{ml} \cdot 100 \mathrm{~m} l^{-1} \cdot \mathrm{min}^{-1}$ immediately after handgrip exercise, and calf blood flow (CBF) to $12.72 \pm 0.72 \mathrm{ml} \cdot 100 \mathrm{ml} l^{-1} \cdot \mathrm{min}^{-1}$ after plantar flexion. These increases in FBF and CBF were not significantly different from those after combined arm and leg exercise. Blood flow to inactive limbs showed no significant changes. Rises in systolic and diastolic blood pressure at the end of exercise were significantly higher after handgrip exercise than after plantar flexion. However, no significant difference was found in mean blood pressure among the three types of exercise. $\dot{V}_{o_{2}}$ and HR in combined exercise were significantly higher than those during handgrip exercise, but no significant difference was found between combined exercise and plantar flexion.

Thus the present results indicated that the circulation to active limbs was not restricted when exercise was performed at $1 / 3 \mathrm{MVC}$, and that inhibitory summation shown in the central respiro-circulatory response to increased active muscle mass could occur without restriction of the peripheral circulation to the active muscle.
\end{abstract}

(Jpn. J. Phys. Fitness Sports Med. 1991, $40: 447 \sim 454$ )

key words : Forearm blood flow, Calf blood flow, Combined exercise, Inhibitory summation

I. 緒

言

全身的運動時の呼吸循環系応答は, 活動筋群が 局所に制限される局所運動時の呼吸循環系応答に 比べて大きい，しかし，身体の複数部位の秎群が 同時に活動を行った時の中心循環応答は, 個々の 筇が単独に活動した時の循環系応答の単純加算に
はならないとされており (Stenberg et al. ${ }^{19)}$, Secher et al. ${ }^{16)}$, Lind and $\mathrm{McNicol}^{20)}$, Davies and Sargeant ${ }^{1)}$, Secher et al. ${ }^{15)}$, Klausen et al..$^{9}$, Grucza et al. ${ }^{5)}$, Seals ${ }^{14)}$ ), 活動筋量の増加が呼吸 循環系応答の大きさをすべて決定するわけではな いと考えられる. その理由は, すでに Secher et al. ${ }^{15)}$ や Klausen et al.9' が明らかにしているよう
*日本女子体育大学基礎体力研究所

干157 東京都世田谷区北烏山8-19-1

**新宿ウェルネスセンター 干160 東京都新宿区西新宿3-2-11

***北鎌倉女子学園高校

干247 神奈川県鎌倉市山ノ内913

****東芝昇降機サービス $\mathrm{K} \mathrm{K}$

干223 神奈川県横浜市港北区茅ヶ崎南1-2-1
Research Institute of Physical Fitness, Japan Women's

College of Physical Education 8-19-1 Kita-karasuyama, Setagaya-ku, Tokyo

Shinjuku Wellness Center 3-2-11 Nishi-shinjuku,

Shinjuku-ku, Tokyo

Kitakamakura Joshi Gakuen High School 913 Yamanouchi, Kamakura-shi, Kanagawa

Toshiba Elevator Service Co. 1-2-1 Chigasakiminami, 
に, 強度の高い他の筋群の活動が付け加えられる と，局所血流が減少することから推察されるよう に，交感神経性の血管収縮が筋活動に伴う代謝性 の血管拡張より優位になることが関係しているの ではないかと思われる。しかし，異なる体肢が同 じ相対的強度 (\%MVC) で同時に運動したときの 全身的な呼吸循環系応答は単純に活動させたとき と変わらない(Lind and $\mathrm{McNicol}^{10)}$ ) とする報告 や，運動の持続時間によって休息肢での血流は減 少する場合と增加する場合があり，それは筋交感 神経活動と連動している (Saito et al. ${ }^{13)}$ ) とする 報告もある、したがって，運動条件によって，活 動筋群の増加に対する呼吸循環系の対応は変わる と思われる. しかし，これまでの報告では他の体 肢の血流減少が運動強度, 持続時間, 活動部位, 活動朌量のどの条件に依存して起こるかについて は明らかではない，また，これまでの研究の多く は, 片手と両手, 片脚と両脚というょうに, 体肢 の片側と両側運動を比較して, 活動筋量の相違に よる呼吸循環応答の相違を検討 ${ }^{1,5,6,14,19)}$ してお り，筋量増加の影響を上・下肢の同時運動によっ て検討した報告は少ない, ${ }^{10,15,16)}$. しか し Taylor

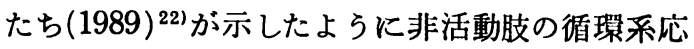
答は, 同側の上肢と対側の下肢では異なっている ので, 体肢の両側運動による能群加算とは別に 上・下肢同時運動による䬢群增加に対する呼吸循 環系の調節を明らかにする必要がある.

本研究は前腕と下腿という筋量の異なる 2 部位 に, 相対的筋収縮強度の等しい動的運動を同時に 行わせて，それぞれの体肢への血流量と全身的な 呼吸循環系応答を単独運動時と比べることによ り, 筋群の加算に伴う呼吸循環系応答の抑制的加 算 (Seals， 198914) )がこの運動条件で生ずるかど らかといらことと，2 部位の活動筋への血流量が 互いに制限しあらかどらかを明らかにすることを 目的にしている.

\section{II. 方法}

\section{A. 被模者}

被検者は年齢 $22.1 \pm 0.12$ 歳, 身長 $156.3 \pm 1.6 \mathrm{~cm}$, 体重 $53.3 \pm 1.98 \mathrm{~kg}$ の健康な体育専攻女子大 学 生
9 名である. 被検者の中に規則的な持久的トレー ニングを行っている人はいなかった，実験前に， 実験目的, 内容, 実験に伴ら危険について説明 し，被検者となることの同意を得た。

\section{B. 実験手順}

被検者はあらかじめ，実験装固を取り付けた状 態で, エルゴメータ運動の練習を行い，垁験装直 に十分慣れるようにした。

1) 最大筋力の測定

実験第 1 日目に最大努力で掌握力, 足底屈力を それぞれ単独に発揮させて，最大等尺性筋力を测 定した。また，掌握と足底屈を同時に行って，各 部位の最大筋力を測定した，掌握力の測定には八 ンドェルゴメータを使用し，中指の第 2 関節が直 角になるようにハンドルを握った位置で最大筋力 を発揮させた．足底屈力の測定は，脚エルゴメー タのペダルに足をのせ，足関節を90度に保った状 態で筋力発揮を行った．測定は 1 分間隔でそれぞ れ 5 回実施して，最大，最小を除く 3 個の値を平 均して個人の最大筋力とした.なお，前腕単独， 下腿単独, 前腕下腿同時筋力測定の順序は任意と し，間には十分な休息をとった。

\section{2) 60 秒間運動}

被検者は仰臥位でハンドェルゴメータあるいは 脚エルゴメータを用いて運動を行った，負荷は単 独に行った掌握力, 足底屈力のそれぞれ $1 / 3 \mathrm{MVC}$ に相当するものとした．運動は60回/分のテンポ で拈もりを $2 \mathrm{~cm}$ 持ち上げる掌握運動 $(\mathrm{H})$ と足関 節を90度の位置から10度伸展する足底屈運動 $(\mathrm{P})$ をそれぞれ単独あるいは同時 $(\mathrm{H}+\mathrm{P})$ に60秒間行 った．運動前は30分間の安静を保ち，運動後は10 分間の回復期をおいた. 3 種の運動は $3 \sim 7$ 日の 間隔をおいて別の日に実施した。

\section{C. 呼吸循摆系応答の測定}

前腕血流量 $(\mathrm{FBF})$ 㧊よび下腿血流量 $(\mathrm{CBF})$ は水 銀封入ラバーストレインゲージを用いて静脈閉塞 法により, 安静時, 運動直後, 回復期に測定した. 各測定30秒前に足首と手首のカフに $260 \mathrm{mmHg}$ の 圧を加えて，手および足への血流を遮断した。 静脈阻止圧は大腿部は $90 \mathrm{mmHg}$, 上腕部は 60 $\mathrm{mmHg}$ とした. 心拍数 $(\mathrm{HR})$ は連続記録した ECG 
の R-R 間隔から算出した，酸素摂取量 $\left(\dot{\mathrm{V}}_{2} \mathrm{O}_{2}\right)$ の 湘定には自動呼吸代謝測定装固（ミナト医科学社 製 RM 300)を用い, 10秒間隔で $\dot{V}_{o_{2}}$ を算出した。 血圧 (BP) は日本コーリン社製の自動血圧装 置 (STBP 680) を用いて上腕の心臓レベルで測定し た.

\section{D. 統計処理}

群間の差の検定には対応のある $\mathrm{t}$ 検定を 使 用 し，危険率 $5 \%$ 以下を有意とした. グループのデ ータはすべて平均值士標淮䛊差で示した。

\section{III. 結果}

足底屈最大筋力は単独発揮 時の $100.0 \pm 5.9 \mathrm{~kg}$ に比べて, 同時発揮では $71.7 \pm 6.5 \mathrm{~kg}$ に有意 $(\mathrm{p}<$ 0.01 )に減少した. しかし, 掌握力は, 単独(31.2士 $1.3 \mathrm{~kg}$ ) に比べて同時発揮の方が低い平均值 $(29.4 \pm 1.5 \mathrm{~kg})$ を示したものの雨平均値間に有意 差は見られなかった。

図 1 と 2 は前腕単独運動 $(\mathrm{H})$ と下腿単独運動 ( $\mathrm{P}$ )時の活動肢と非活動肢の血流量を示したもの である. 図 1 の活動肢の FBF は運動終了直後に $9.64 \pm 1.00 \mathrm{ml} \cdot 100 \mathrm{ml}^{-1} \cdot \mathrm{min}^{-1}, 30$ 秒後はそれより 高い $10.39 \pm 0.70 \mathrm{ml} \cdot 100 \mathrm{ml}^{-1} \cdot \mathrm{min}^{-1}$ に增加した が，それ以後は緩やかに低下した。 それに対して， 非活動肢の CBF は有意の変化を示さなかった。

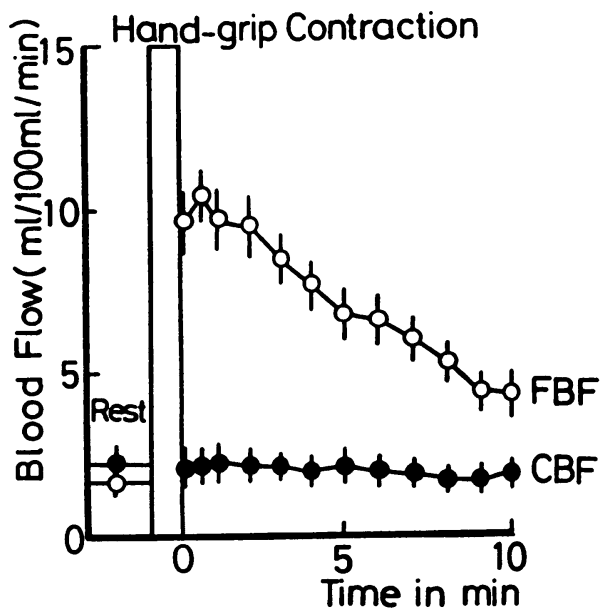

Fig. 1. Forearm (active) and calf (inactive) blood flow after dynamic handgrip exercise. (FBF ; Forearm blood flow, CBF ; Calf blood flow)

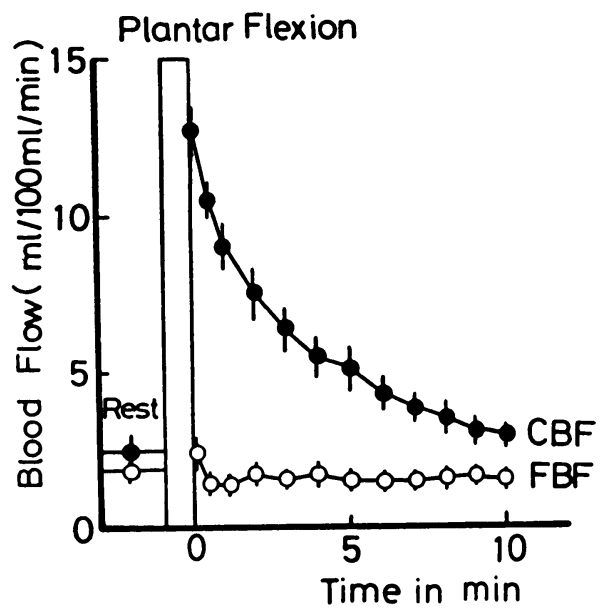

Fig. 2. Calf (active) and forearm (inactive) blood flow after dynamic plantar flexions.

図 2 では活動肢の CBF が運動終了直後 $12.72 \pm$ $0.72 \mathrm{ml} \cdot 100 \mathrm{ml}^{-1} \cdot \mathrm{min}^{-1}$ に增加し, その後は[H]運 動後の FBF に比べて急激な减少を示した. それに 対して非活動肢の FBF は運動終了直後には安静 時 $\left(1.88 \pm 0.18 \mathrm{ml} \cdot 100 \mathrm{ml}^{-1} \bullet \mathrm{min}^{-1}\right)$ より高い $2.52 \pm$ $0.45 \mathrm{ml} \cdot 100 \mathrm{ml}^{-1} \cdot \mathrm{min}^{-1}$ を示したが有意美はなか った. しかし，30秒， 1 分後は直後より低い值 を示した. 30 秒後の值 $\left(1.50 \pm 0.23 \mathrm{ml} \cdot 100 \mathrm{~m} l^{-1}\right.$ ・ $\left.\mathrm{min}^{-1}\right)$ は直後に対しして有意 $(\mathrm{p}<0.05)$ に低か った. 図 3 は同時運動 $[\mathrm{H}+\mathrm{P})$ での FBF, CBF を

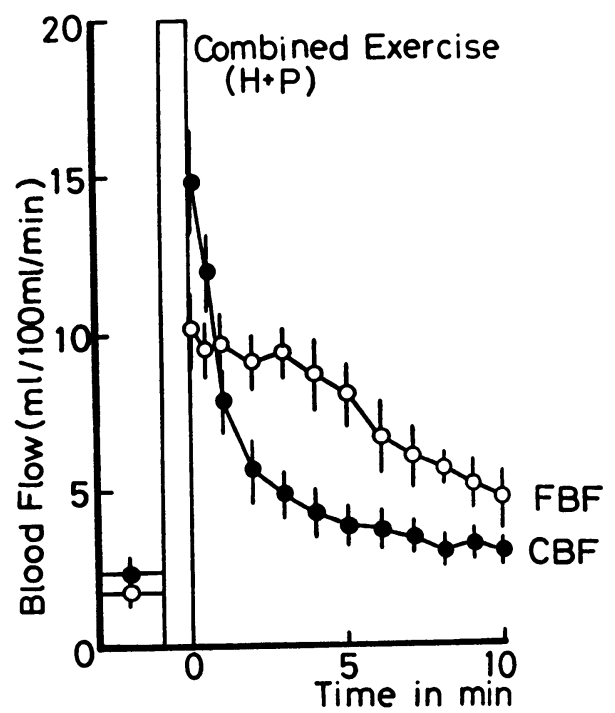

Fig. 3. Forearm(active)and calf(active)blood flow after combined arm plus leg exercise. 
示したものである.どちらも図 1,2 の単独運動 時の血流量とほぼ同じ様に変化し, FBF は CBF より緩やかに減少した. 運動終了直後の FBF, $\mathrm{CBF}$ の安静時からの増加分は, 図 4 亿示す通り である. 各体肢の単独運動 $([\mathrm{H}]$ あるいは $(\mathrm{P}])$ 時 と両体肢の同時運動 $[\mathrm{H}+\mathrm{P}]$ 時の血流量の間に有 意差はなかった。

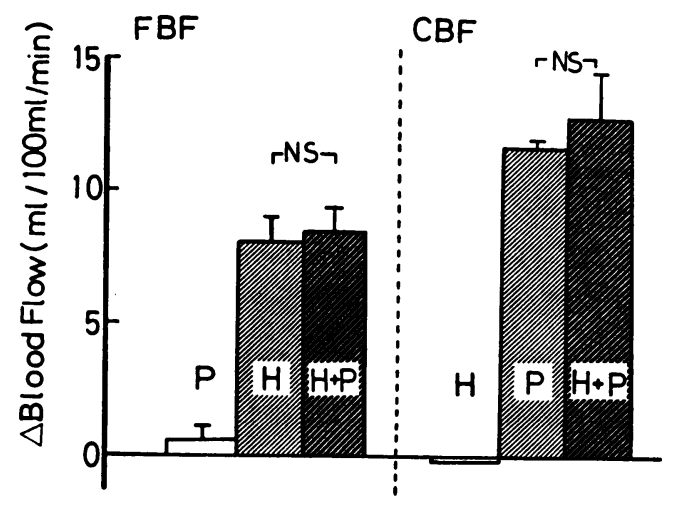

Fig. 4. Comparison of blood flow increase immediately after arm and leg exercise performed seperately $(\mathrm{H}, \mathrm{P})$ and simultaneously $(\mathrm{H}+\mathrm{P}) .(\mathrm{H}$; handgrip exercise, $\mathrm{P}$; plantar flexions, $\mathrm{H}+\mathrm{P}$; combined handgrip plus plantar exercise)

運動終了時の収縮期血圧(SBP), 弛 緩 期 血 圧 (DBP) ともに[H]が最も高く(120.1 $\pm 4.2 \mathrm{mmHg}$, $81.11 \pm 4.37 \mathrm{mmHg}) ，(\mathrm{H}+\mathrm{P})$ に比べて有意であ ったが，他はいずれる有意差がなかった，平均血 圧 [(収縮期血圧一弛緩期血圧) $/ 3+$ 弛緩期血圧) $]$ は 3 運動間に有意差はなかった。

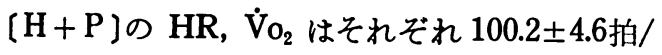
分, $7.84 \pm 0.77 \mathrm{ml} \cdot \mathrm{kg}^{-1} \cdot \mathrm{min}^{-1}$ であり, (H)の $87.6 \pm 4.1$ 拍/分, $5.75 \pm 0.36 \mathrm{ml} \cdot \mathrm{kg}^{-1} \cdot \mathrm{min}^{-1}$ より 有意( $\mathrm{p}<0.01)$ に高かった. しかし（P〕の 98.6士 5.1 拍/分および $7.06 \pm 0.83 \mathrm{ml} \cdot \mathrm{kg}^{-1} \cdot \mathrm{min}^{-1}$ と比べ るとどちらの平均値も $[\mathrm{H}+\mathrm{P}]$ の方がやや高かっ た $\left(\mathrm{HR}: 102 \%, \dot{\mathrm{V}}_{\mathrm{o}_{2}}: 111 \%\right)$ ものの有意差はな かった．安静時からの增加分を比較すると図 5 ,

6 の通りである. 単独運動 $[\mathrm{H}]$ の $\mathrm{HR}, \dot{\mathrm{V}}_{2}$ は [P]および同時運動の $[\mathrm{H}+\mathrm{P}]$ に対して, 有意 $(\mathrm{p}<0.05)$ に低かった. しかし, 同時運動 $[\mathrm{H}+\mathrm{P}]$ の $\mathrm{HR}, \dot{\mathrm{V}}_{2}$ はともに単独運動 $[\mathrm{P}]$ より高い平均

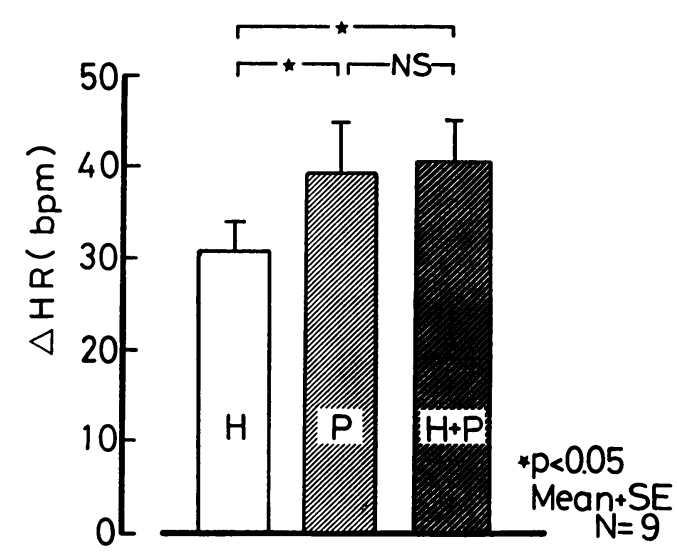

Fig. 5. Increase in heart rate during arm and leg exercise.

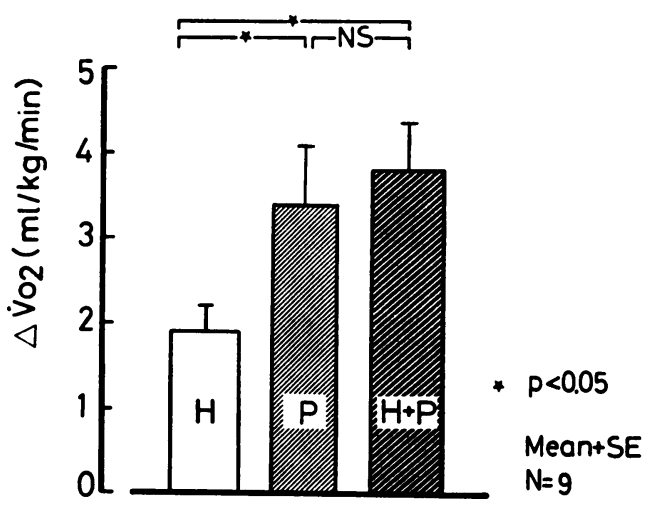

Fig. 6. Increase in $\dot{\mathrm{V}}_{2}$ during arm and leg exercise.

值を示したものの，有意差はなかった。

\section{IV. 論}

全身的な呼吸循環系応答に対して, 筋量の増加 がどのように関係しているかについては，片手の 運動と両手の運動, 片脚運動と両脚運動といらよ らに体肢の両側をモデルとして研究したものが多 い. その場合両側運動で活動する筋量は, 片側運 動のほぼ 2 倍になるはずであるが, 心拍出量, 心 拍数, 血圧, 筋交感神経活動などの循環系応答は 筋量の增加に比べて小さいか, (Davies and Sargeant $^{1)}$, Imms と Mehta ${ }^{6)}$, Seals $\left.{ }^{14)}\right)$, 変わらない (Stenberg et al. ${ }^{19)}$, Lind and $\mathrm{McNicol}^{10)}$, Klausen et al.9), Grucza et al. $\left.{ }^{51}\right)$ と報告されている. この様な結果は非活動肢の 血流減少 (Eklund et 
al. ${ }^{3)}$, Kitamura et al. ${ }^{8)}$, Klausen et al. ${ }^{91}$, Gaffney et al.4), Saito et al. $^{131}$ ) や強度の低い活動時の筋 で見られる血流減少(Secher et al. $\left.{ }^{151}\right)$ から示唆さ れるように活動筋群の増加が末梢の特定部位での 血流減少を起こすことが一つの原因であると考え られている. しかし，他の非活動体肢の循環系に 対する影響は，上下肢のそれぞれの対側肢に対す るものと，上肢と下肢間の影響とでは異なるとさ れている(Taylor et al. $\left.{ }^{221}\right)$. また, その影響は加 えられた運動の強度(Secher et al. ${ }^{14)}$ ) や時間(Gaffney et al.4), Saito et al. ${ }^{21)}$, Taylor et al. $\left.{ }^{22)}\right)$ によ っても異なることを示唆する報告がなされてい る. しかし, 活動中の他の体肢の末梢偱環に影響 を及ぼす運動の条件についてはこれまで明らかに されなかった。

本研究は, 収縮強度が相対的に等しい(1) $3 \mathrm{MVC}$ ) 60 秒間の掌握運動 $[\mathrm{H}]$ と足底屈運動 $[\mathrm{P}]$ が互いにどう影響するかを体肢の血流量と HR, $\mathrm{BP}, \dot{\mathrm{V}}_{2}$ から明らかにしよらとした. 実際に発揮 できる筇力の最大值は単独運動より同時運動の方 が低く，特に足底属力は有意な低下を示した。し たがって，本研究で与.壳られた負荷は各体肢が単 独に発揮した最大筋力を基準としてみれば，前 腕・下腿の両体肢で等しいが，闰時運動時に発揮 し得る筋力の最大值を基準としてみれば前腕より 下腿の方が高いことになる. 本研究の結果, 前腕 と下腿の運動を同時に行っても，運動終了時血流 量は単独運動時と相違のないことが明らかになっ た. 下肢運動時の $\dot{\mathrm{V}}_{\mathrm{O}_{2}}$ に対する上肢運動時の $\dot{\mathrm{V}}_{\mathrm{O}_{2}}$ は 70 85\% (Stenberg et al. ${ }^{19}$ ), Secher et al. ${ }^{16)}$, Karlsson et al. ${ }^{7)}$ )であるとされている. 本 研究のプロトコールでも, 活動筋量は前腕より下 腿の方が大きいと考えられ, 実際に $\dot{V}_{o_{2}}$ 増加量も 下腿運動時の方が有意に高かった. それにも拘ら ず Secher たち(1977) ${ }^{15)}$ の示したよらな血流量減 少は起こらなかった. 本研究では Secher たちの 研究と違って両体肢の相対的運動強度を等しくし ていることを考えると，一つの体肢の運動が，活 動している他の体肢へ影響を与えるかどらかは筋 量ではなく筋収縮の相対的強度に依存しているこ とが示唆される. Taylor たち(1989) ${ }^{221}$ は脚運動
時に非活動肢の腕あるいは脚での血管抵抗の増加 は運動強度(\%peak $\dot{V}_{\mathrm{O}_{2}}$ )が高くなるほど顕著であ ることを示している．また， $\mathrm{P}_{\mathrm{H}}$ の低下を起こす ような強度の前腕運動は下腿の血管収縮を起こす (Sinoway et al. ${ }^{16)}$, Systrom et al. ${ }^{201}$ ) ことや前腕 運動の強度が高くなると筋交感神経活動が高くな る(Saito et al. $\left.{ }^{12)}\right)$ ことは, 複数筋が同時に活動し た後，他の体肢の循環系応答に影響を与える要因 として筋収縮強度の関与が大きいことを示唆して いる. Saito たち(1986) ${ }^{12)}$ の結果では, 収縮張力 が45\%MVC になると，著しい筋交感神経活動の 増加が起こっているが，1/3 MVC 強度でも非活 動肢での筋交感神経活動の増加や血管収縮が観察 されている (Saito et al. ${ }^{13)}$ )。したがって，本研究 で用いた 1/3 MVC は非活動肢での血管収縮を引 き起こす可能性のある強度である.ささらに, Seals $(1989)^{14)}$ の報告によれば, 両側の掌握運動時の筋 交感神経活動は単独運動より高い值を示してい る. それにも拘らず，本研究のように活動してい る他の体肢では血流減少が起きなかったといらこ とは，代謝性の血管昖張がそれを上回ったことを 示唆している.

一方，体肢の両側の筋力を同時に発揮させると 片側づつ単独発揮させた時より小さくなるといら Ohtsuki (1983) ${ }^{111}$ や Secher たち(1988) ${ }^{17)}$ の報告 から考えると, 複数部位で同時に一定張力を発揮 させるためには，骨格筋を支配する中枢神経系の 興奮水準が単独運動より相対的に高くなければな らないと思われる。また，Fujiwara たぢ付肘屈 曲運動時の $\mathrm{H} 反$ 射が同側の下肢（非活動肢）では 促進的に，対側の下肢では抑制的になること，そ の影響は\%MVが高いほど大きいことを示して いる.このように自律神経系のみならず体性神経 系に拈いても，一つの体肢の運動は他の体肢を支 配寸る神経系の興奮・抑制に影響を与えているの で, 本研究の結果はそれらとも関連させてとらえ る必要があろう。また, Taylor たち(1988) ${ }^{22)}$ は 活動筋の post-exercise hyperemia が筋の電気的 活動の増加に伴って増加すると述べているので， 上肢と同側の下肢の同時運動では, 骨格筋での代 謝性の血管払張性刺激は単独運動時に比べて大き 
くなっているはずである. しかし，それにも拘ら ず単独運動時と同時運動時の血流量増加に差が生 じなかったという本研究の結果は同時運動によっ て増加した血管収縮性刺激は, 同運動で増加した 代謝性血管払張を抑える程度のものであったこと を示すものである. そして，血流量の増減は一つ の筋の張力の大きさだけではなく, 同時に活動す る他の筋との相対的強度に依存して変化するもの といえる. Secherたち(1977) ${ }^{15)}$ の示した両体肢の $\dot{V}_{\mathrm{O}_{2}}$ の割合があるレベルを超えると血流減少が起 きるという結果は，加えられた運動体肢の筋量の 影響を示すだけでなく強度の因子の影響をも示唆 しているものと考劣るとができる.

次に, HR や $\dot{V}_{O_{2}}$ のような中权性の呼吸循環応 答の大きさが，複数筋の同時運動によって加算さ れていくかどらかについてみると，本研究の最大 下負荷運動の加算においても，単独運動の $\dot{V} o_{2}$, HR の両体肢の加算よりは小さいことが明らかに なった.これは上肢, 下肢に最大運動を行わせ て, 同時運動時の $\dot{V} \mathrm{o}_{2}$ や $\mathrm{HR}$ を単独運動時と比 較したこれまでの報告(Stenberg et al. ${ }^{19)}$, Lind and $\mathrm{McNicol}^{10)}$, Secher et al. ${ }^{16)}$, Secher et al. ${ }^{15)}$, Klausen et al. ${ }^{91}$ ) と一致するものである. 本研究 では, Secher たち(5)や Klausen たち9/のように, 活動筇群の加算による活動肢での血流減少は起こ らなかったにも拘らず $\dot{V}_{o_{2}}$ や HR は抑制的加算 (inhibitory summation, Seals 198914) )になった. したがって， $\dot{V}_{o_{2}}$ や HR が活動筋量の增加に比へ て小さいという結果は, 必ずしも活動筋群の血流 減少によってのみ説明されるものではないことが 示唆された.

本研究のように, 活動体肢への血流減少がない にも拘らず，同時運動の呼吸循環系応答が両体肢 を単独に運動させたときの単純加算にならないと いらことは，もし呼気で測定した $\dot{V}_{\mathrm{O}_{2}}$ が活動筋 の $\dot{V}_{O_{2}}$ を表すとすれば, そこでの動静脈酸素較差 は同時運動で減少したことになる．しかし，片脚 運動と両脚運動時の動静脈酸素較差を調べた Klausen たち(1982) 9)の報告ではそのような結果 は得られていない。 また, 掌握運動では, 片側運 動時より両側運動時の方が HR の増加があるにも
拘らず, 1 回拍出量 (SV) は減少し, 心拍出量 (Q்) は変わらない(Grucza et al. ${ }^{\text {l) }}$ ) ことが示されてい

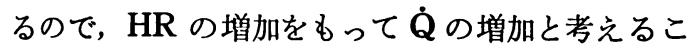
とはできない，本研究のような負荷条件の運動で 増加した両体肢への血液供給が，市の増加を伴。 たものであるか，Q Q 増加なしに末梢的な血流分 配の変化によるものであるかは興味あるところで あるが，本研究ではそれを説明するデータは得ら れていない.

末梢循環系に抑制が起きない状態で，全身的な 呼吸循環系が筋量の増加に比例した増加をみせな い理由の一つとして, 次のような可能性も考えら れる. 本研究の $\Delta \dot{V}_{O_{2}}$ や $\Delta \mathrm{HR}$ は運動による骨格 筋の酸素摂取量の増加だけに応答したのではな く，呼吸筋や心筋などの骨格筋以外の部位での代 謝の高進をも反映するものである．同時運動 $[\mathrm{H}+\mathrm{P}]$ の応答が単独運動 $[\mathrm{H}]$ と $[\mathrm{P}]$ の応答の加 算ではないといらことは, 骨格筋以外の部位から の需要に対する中权性の呼吸循環系応答が，同時 運動でも著しく増加するわけでないことを示唆し ており，それが抑制的加算を生じた原因になって いるかもしれない.しかし，この点については， 本研究からは説明できないので，今後さらに検討 されねばならない。

\section{V. 要 約}

本研究は, 相対的筋収縮 強 度 の 等 しい $(1 / 3$ MVC) 動的運動を前腕と下腿に同時に行わせて, 筋群の増加に伴う呼吸循環系応答の抑制的加算が この運動条件で生ずるかどらかといらことと， 2 部位の活動筋への血流量が互いに制限しあらかど らかを明らかにすることを目的にしている，被検 者は活動的な女子大学生 9 名であり, 対象とした 運動はテンポ60回/分の掌握運動 $[\mathrm{H}]$ と足底屈運 動 [P]および前腕・下腿同時運動 $[\mathrm{H}+\mathrm{P}]$ であ った. いずれも運動時間は60秒である. 得られた 結果を要約すると以下の通りである.

1) 掌握力と足底屈力を同時に発揮させると， どちらもそれぞれを単独で発揮したときより小さ くなり，特に足底屈筋力の低下は有意 $(\mathrm{p}<0.01)$ であった。 
2) 1/3 MVC 負荷での動的掌握運動 $[H]$ ある いは足底屈運動 $[\mathrm{P}]$ を，それぞれ単独に60秒間行 った時の活動肢の血流量 (FBF, CBF) は9.64士 $1.00 \mathrm{ml} \cdot 100 \mathrm{ml}^{-1} \cdot \mathrm{min}^{-1}$ と $12.72 \pm 0.72 \mathrm{ml} \cdot 100$ $\mathrm{m}^{-1} \cdot \mathrm{min}^{-1}$ に増加した。

3) 単独運動 $[\mathrm{H}]$ 時の非活動肢の $\mathrm{CBF}$ は有意 の変化を示さなかった. 単独運動[P]時の非活動 肢の血流量 FBF も運動直後は安静時より高い平 均値を示したものの, 有意差はなかった.

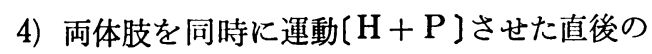
血流量は, $\mathrm{FBF}, \mathrm{CBF}$ ともに, 単独運動直後の平 均值と有意差はなかった。

5）運動終了時の血圧は, 収縮期, 昖張期とも に〔H]運動がもっとも高く，[H+P]運動に比べ て有意であった。しかし，平均血圧は，3運動間 に有意差はなかった。

6) 同時運動 $[\mathrm{H}+\mathrm{P}]$ の $\mathrm{HR}, \dot{\mathrm{V}}_{\mathrm{O}_{2}}$ はそれぞれ $100.2 \pm 4.6$ 拍/分, $7.84 \pm 0.77 \mathrm{ml} \cdot \mathrm{kg}^{-1} \bullet \mathrm{min}^{-1}$ であ り，〔H]より有意 $(\mathrm{p}<0.01)$ 飞高かったが, [ $\mathrm{P}\}$ と 比べると，どちらの平均値も有意差はなかった。 安静時からの増加分を比較しても, $[\mathrm{H}+\mathrm{P}]$ 運動 時の $\mathrm{HR}, \dot{\mathrm{V}} \mathrm{O}_{2}$ は単独運動 [H] と[P]の $\mathrm{HR}, \dot{\mathrm{V}}_{2}$ を加算したものより小さかった。

7) 本研究の結果から，1/3 MVC に相当する 張力を発揮して行ら前腕と下腿の60秒間同時運動 では, 両体肢への血液供給は互いに制限し合うこ となく, 単独運動時と同レベルの血流量が確保さ れることが示された。 それにも拘らず $\mathrm{HR}, \dot{\mathrm{V}}_{\mathrm{o}_{2}}$ は単純加算より小さくなって括り, 全身的な呼吸 循環応答に見られる抑制的加算は活動筋への血流 減少がなくても起こりらることが示唆された.

本研究の要旨は, 第45回日本体力医学会に拈いて報告 した.

(受付 平成 3 年 1 月 9 日)

文

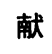

1) Davies, C. T. M. and Sargeant, A. J. (1975): Effects of training on the physiological responses to one- and two-leg work. J. Appl. Physiol., 38, 377381.
2) Eklund, B., Kaijser, L. and Knutsson, E. (1974) : Blood flow in resting (contralateral) arm and leg during isometric contraction. J. Physiol., 140, 111-124.

3) Fujiwara, T., Yanagisawa, K., and Hanaoka, M. (1988) : Modification of lower extremity motoneuron activities by volitional contraction of elbow flexor muscle in man. New Horizons of Human Movement. SOSCOC Abst. III pp 120-121.

4) Gaffney, F. A., Sjogaard, G. and Saltin, B. (1990): Cardiovascular and metabolic responses to static contraction in man. Acta Physiol. Scand., 138, 249-258.

5) Grucza, R., Kahn, J., Cybulski, G., Niewiadomski, W., Stupnicka, E. and Nazar, K. (1989) : Cardiovascular and sympatho-adrenal responses to static handgrip performed with one and two hands. Eur. J. Appl. Physiol., 59, 184-188.

6) Imms, F. J. and Mehta, D. (1989) : Respiratory responses to sustained isometric muscle contraction in man : the effect of muscle mass. J. Physiol., 419, 1-14.

7) Karlsson, J., Bonde-Petersen, F., Henriksson, J. and Knuttgen, H. G. (1975) : Effects of previous exercise with arm or legs on metabolism and performance in exhaustive exercise. J. Appl. Physiol., 38, 763-767.

8) Kitamura, K., Yasuda, Y., Miyamura, M. and Matsui, H. (1980): Blood flow of the ipsilateral and contralateral lower limbs after isometric contraction. Jap. J. Physiol., 30, 301-304.

9) Klausen, K., Secher, N. H., Clausen, J. P., Hartling, O. and Trap-Jensen, J. (1982): Central and regional circulatory adaptations to one-leg training. J. Appl. Physiol., 52, 976-983.

10) Lind, A. R. and McNicol, G. W. (1967) : Circulatory responses to sustained handgrip contractions performed during other exercise, both rhythmic and static. J. Physiol., 192, 595-607.

11) Ohtsuki, T.(1983): Decrease in human voluntary isometric arm strength induced by simultaneous bilateral exertion. Bihav Brain Res. 7, 165-178.

12) Saito, M., Mano, T., Abe, H. and Iwase, S.(1986): Responses in muscle sympathetic nerve activity 
to sustained hand-grip of different tension in humans. Eur. J. Appl. Physiol., 55, 493-498.

13) Saito, M., Mano, T. and Iwase, S.(1990): Changes in muscle sympathetic nerve activity and calf blood flow during static handgrip exercise. Eur. J. Appl. Physiol., 60, 277-281.

14) Seals, D. R. (1989) : Influence of muscle mass on sympathetic neural activation during isometric exercise. J. Appl. Physiol., 67, 1801-1806.

15) Secher, N. H., Clausen, J. P., Klausen, K., Noer, I. and Trap-Jensen, J. (1977) : Central and regional circulatory effects of adding arm exercise to leg exercise. Acta Physiol. Scand., 100, 288-297.

16) Secher, N. H., Larsen, N. R., Binkhorst, R. A. and Bonde-Petersen, F. (1974) : Maximal oxygen uptake during arm cranking and combined arm plus leg exercise. J. Appl. Physiol., 36, 515-518.

17) Secher, N. H., Rube, N. and Elers, J. (1988) : Strength of two- and one-leg extension in man. Acta Physiol. Scand. 134, 333-339.

18) Sinoway, L., Prophet, S., Gorman, I., Mosher, T., Shenberger, J., Dolecki, M., Briggs, R. and Zelis,
R. (1989) : Muscle acidosis during static exercise is associated with calf vasoconstriction. J. Appl. Physiol., 66, 429-436.

19) Stenberg, J., Åstrand, P. -O., Ekblom, B., Royce, J. and Saltin, B. (1967) : Hemodynamic response to work with different muscle groups, sitting and supine. J. Appl. Physiol., 22, 61-70.

20) Systrom, D. M., Kanarek, D. J., Kohler, S. J. and Kazemi, H. (1990): ${ }^{31} \mathrm{P}$ nuclear magnetic resonance spectroscopy study of the anaerobic threshold in humans. J. Appl. Physiol., 68, 20602066.

21) Taylor, J. A., Chase, P. B., Enoka, R. M. and Seals, D. R.(1988) : Cardiovascular adjustments to rhythmic handgrip exercise : relationship to electromyographic activity and post-exercise hyperemia. Eur. J. Appl. Physiol., 58, 32-38.

22) Taylor, J. A., Joyner, M. J., Chase, P. B. and Seals, D. R.(1989) : Differential control of forearm and calf resistance during one-leg exercise. J. Appl. Physiol., 67, 1791-1800. 